ҚАЗАҚСТАН АУЫЛ ШАРУАШЫЛЫҒЫНЫН ТЕХНИКАЛЫҚ ЖАРАҚТАНДЫРЫЛУЫ ОНЫҢ БӘСЕКЕГЕ ҚАБІЛЕТТІЛІГІНІҢ ӨСУ ФАКТОРЫ РЕТІНДЕ

\title{
TECHNICAL EQUIPMENT OF AGRICULTURE IN KAZAKHSTAN AS A FACTOR OF INCREASING ITS COMPETITIVENESS
}

\section{ТЕХНИЧЕСКАЯ ОСНАЩЕННОСТЬ СЕЛЬСКОГО ХОЗЯЙСТВА КАЗАХСТАНА КАК ФАКТОР РОСТА ЕГО КОНКУРЕНТОСПОСОБНОСТИ}

\author{
А.Б. МОЛДАШЕВ ${ }^{1 *}$ \\ э.F.Ә., профрессор \\ М. КАМЫСБАЕВ 2 \\ э.Ғ.Ә., профрессор \\ ${ }^{1}$ Қазақ аграрлық-өнеркәсіптік кешенінің экономикасы және ауылдық аумақтарды \\ дамыту ғылыми-зерттеу институты, Алматы, Қазақстан \\ ${ }^{2}$ Халықаралық ақпараттық технологиялар университеті, Алматы, Қазақстан \\ *автордың электрондық поштасы: moldashev48@mail.ru \\ A. MOLDASHEV * \\ D.E.Sc., Professor \\ M. KAMYSBAYEV ${ }^{2}$ \\ D.E.Sc., Professor \\ ${ }^{1}$ Kazakh Research Institute of Economy of Agro-Industrial Complex and Rural Development, \\ Almaty, Kazakhstan \\ ${ }^{2}$ International University of Information Technologies, Almaty, Kazakhstan \\ *corresponding author e-mail: moldashev48@mail.ru \\ А.Б. МОЛДАШЕВ ${ }^{1 *}$ \\ Ә.э.н., профрессор \\ М.К. КАМЫСБАЕВ ${ }^{2}$ \\ Ә.э.н., профрессор \\ ${ }^{1}$ Казахский научно-исследовательский институт экономики агропромышленного \\ комплекса и развития сельских территорий, Алматы, Казахстан \\ ${ }^{2}$ Международный университет информационных технологий, Алматы, Казахстан \\ электронная почта автора: moldashev48@mail.ru
}

\begin{abstract}
Аңдатпа. Технологиялық инновацияларды игерудің, отандық азық-түліктің бәсекеге қабілеттілігін арттырудың материалдық негізі техникалық әлеует болып табылады. Зертmеу мақсаты - Қазақстанның агроөнеркәсіптік кешенін ауыл шаруашылығы техникасымен қамтамасыз етудің қазіргі жай-күйін зерделеу, ауыл шаруашылығы машинасын жасаудың негізгі проблемалары мен перспективаларын анықтау. Экономикалық-статистикалық әдісті қолдану негізінде республикада 2013-2020 жылдары ауыл шаруашылығы техникасының негізгі түрлерінің болуына талдау жүргізілді. Статистикалық деректерді қарау ауыл шаруашылығы өндірісін техникалық жарақтандыру оның тиімді дамуын айқындайтын факторлардың бірі болып табылатынын куәландырады. Нәтижесінде - ауыл шаруашылығы тауарын өндірушілердің техникалық базасын қалыптастыру бойынша жақын және алыс шетелдердің тәжірибесі ұсынылған және ел экономикасының тұрақты дамуындағы аграрлық сектордың рөлі негізделген. ҚР АӨК дамытудың 2017-2021 жылдарға арналған мемлекеттік бағдарламасын ескере отырып, ауыл шаруашылығы машиналарының негізгі түрлерін шығару серпіні көрсетілген. Ауыл шаруашылығы саласын материалдық-техникалық қамтамасыз етудің түйінді проблемалық мәселелері: техниканың тозуы, пайдаланудың нормативтік мерзімінен асып кетуі, техникалық жарақтандырудың әлсіздігі, ауыл шаруашылығы жабдықтарының қымбаттығы көрсетілген. Әр түрлі ауылшаруашылық технологияларын шығаратын отандық кәсіпорындар туралы мәліметтер келтірілген. Қорытындысы - талдау негізінде авторлар ауыл шаруашылығы машиналарының отандық өндірісі көлемінің жеткіліксіздігіне байланысты олардың негізгі саны мен түрлері Ресей,
\end{abstract}




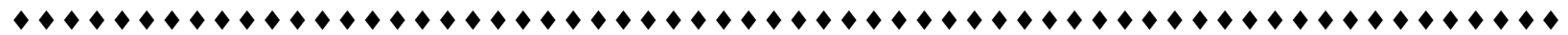

Беларусь, Украина және алыс шетел мемлекеттерінен жеткізілетінін атап өткен. Ауыл шаруашылығына арналған техниканы жеткізушілер туралы машиналардың атауы мен маркасы көрсетілген ақпарат берілген. Жүргізілген зерттеулер нәтижесінде АӨК техникалық құралдарын жаңарту үшін ауыл шаруашылығы машинасын жасауды дамыту қажеттілігі негізделген. Осы мақсатта Қазақстан Республикасының агроөнеркәсіптік өндірісінің техникалық жарақтандырылуын арттыруға мүмкіндік беретін іс-шаралар кешені әзірленген.

Abstract. The material basis for the development of technological innovations, increasing the competitiveness of domestic food is technical potential. The purpose of the study is to study the current state of provision of agro-industrial complex of Kazakhstan with agricultural machinery, to identify the main problems and prospects of agricultural engineering. Based on the use of economic and statistical method, the analysis of the availability of the main types of agricultural machinery in the republic for 2013-2020 was done. Consideration of statistical data indicates that technical equipment of agricultural production is one of the determining factors for its effective development. Results - the experience of the CIS and foreign countries in the formation of technical base of agricultural producers is presented and the role of agricultural sector in sustainable development of the country's economy is justified. The dynamics of the output of the main types of agricultural machines is shown, taking into account the State Program on Development of the AIC of the RK for 2017-2021. The key problematic issues of material and technical support of agricultural industry are reflected: wear and tear of equipment, excess of standard service period, weak technical means, high cost of agricultural equipment. The data on domestic enterprises producing various agricultural machinery are presented. Conclusions - based on the analysis, the authors note that due to insufficient volumes of domestic production of agricultural machinery, their main quantity and types are supplied from Russia, Belarus, Ukraine and foreign countries. Information about suppliers of agricultural machinery is presented, indicating the name and brand of machinery. As a result of the conducted research, the necessity of development of agricultural machinery for updating technical means of agro-industrial complex has been justified. For these purposes, a set of measures aimed to improve technical equipment of agro-industrial production of the Republic of Kazakhstan has been developed.

Аннотация. Материальной основой освоения технологических новаций, повышения конкурентоспособности отечественного продовольствия является технический потенциал. Цель исследования - изучение современного состояния обеспеченности сельскохозяйственной техникой агропромышленного комплекса Казахстана, выявление основных проблем и перспектив сельскохозяйственного машиностроения. На основе применения экономикостатистического метода был проведен анализ наличия основных видов сельхозтехники в республике за 2013-2020 годы. Рассмотрение статистических данных свидетельствует о том, что техническое оснащение сельскохозяйственного производства является одним из определяющих фракторов его эффективного развития. Результаты - представлен опыт стран ближнего и дальнего зарубежья по формированию технической базы сельхозтоваропроизводителей и обоснована роль аграрного сектора в устойчивом развитии экономики страны. Показана динамика выпуска основных видов сельскохозяйственных машин, с учетом Государственной программы развития АПК РК на 2017-2021 годы. Отражены ключевые проблемные вопросы материально-технического обеспечения сельскохозяйственной отрасли: износ техники, превышение нормативного срока эксплуатации, слабое техническое вооружение, дороговизна сельскохозяйственного оборудования. Приведены данные об отечественных предприятиях, выпускающих различную агротехнику. Выводы - на основе анализа авторы отмечают, что из-за недостаточности объемов отечественного производства сельхозмашин основное их количество и виды поставляются из России, Беларуси, Украины и государств дальнего зарубежья. Дана информация о поставщиках техники для сельского хозяйства с указанием наименования и марки машин. В результате проведенных исследований обоснована необходимость развития сельскохозяйственного машиностроения для обновления технических средств АПК. В этих целях разработан комплекс мероприятий, позволяющий повысить техническую оснащенность агропромышленного производства Республики Казахстан.

Түйінді сөздер: агроөнеркәсіптік кешен, материалдық-техникалық база, ауыл шаруашылығы техникасы, импорт, ауыл шаруашылығы машинасын жасау, еңбек өнімділігі, азық-түлік қауіпсіздігі, мемлекеттік қолдау.

Key words: agro-industrial complex, material and technical base, agricultural machinery, import, agricultural engineering, labor productivity, food security, government support. 

хозяйственная техника, импорт, сельскохозяйственное машиностроение, производительность труда, продовольственная безопасность, государственная поддержка.

Кіріспе. Агроөнеркәсіптік кешен Қазақстан экономикасының маңызды құрамдас бөлігі болып табылады, онда қоғам үшін өмірлік маңызды өнім өндіріледі. Аграрлық саланы дамыту шешуші шамада бүкіл экономикалық әлеуеттің жай-күйін, мемлекеттің азық-түлік қауіпсіздігінің деңгейін және қоғамдағы әлеуметтік-экономикалық жағдайды айқындайды [1]. Агроөнеркәсіптік кешеннің маңызды буыны ауыл шаруашылығы болып табылады. Ол агроөнеркәсіп кешенінде ғана емес, еліміздің бүкіл экономикасында ерекше орын алады.

Ауыл шаруашылығын елді азық-түлікпен және өнеркәсіпті шикізатпен қамтамасыз ететін сала ретінде ғана қарастыру, оның маңыздылығын айқындай алмайды. Бұл саланың өнеркәсіп өніміне тапсырыс беруші және тұтынушы ретіндегі стратегиялық рөлі де аз емес, түптеп келгенде ел экономикасының түрлі салаларындағы пайданы қалыптастыратын сала ретінде қарастыруға болады. Экономиканың тұрақты жағдайында ауыл шаруашылығындағы бір жұмысшы, басқа саладағы 7-8 жұмысшыны жұмыспен қамтиды.

Ауыл шаруашылығы өндірісі дамуының жоғары деңгейі, оның төлем қабілеттілігі, ондаған саланың өнімі болып табылатын материалдық-техникалық ресурстарды (техника, қосалқы бөлшектер, химияландыру құралдары, энергия ресурстары және т.б.) сатып алу мүмкіндігі ел экономикасының тұрақты дамуын айқындайды.

2020 жылдың мәліметтері бойынша Қазақстан Республикасындағы ауыл шаруашылығы дақылдарының жалпы егіс алқабы 22,2 млн гектарды құрайды, осы көлемнің 13,1 млн га ауыл шаруашылық кәсіпорындарына, 8,9 млн га шаруа қожалықтарға және 0,2 млн га жеке қосалқы шаруашылықтарға тиесілі [2].

Қазіргі кезеңде Қазақстан Республикасының агроөнеркәсіптік кешенін дамытудың 2017-2021 жылдарға арналған мемлекеттік бағдарламасы және де АӨК салаларын және ауылдық өңірлерді дамытуды қозғайтын бірқатар мемлекеттік бағдарламалар іске асырылуда [3].

Басым бағдарламалардың табысты іске асырылуына және мақсатты көрсеткіштерге қол жеткізуге қарамастан, ауыл шаруашылығы инфрақұрылымын жаңарту және АӨК материалдық-техникалық базасын дамыту, шаруа (фермер) қожалықтарын қазіргі заманғы машиналар паркімен, ар- найы жабдықтармен қамтамасыз ету, гидротехникалық құрылыстарды салу және суармалы алқаптарды қайта жаңарту, ауылды әлеуметтік жайластыру, қызметкерлердің кадрлық құрамын сақтау және жаңарту сияқты шешілмеген проблемалар көп [4].

Зерттеу материалдары мен әдістері. Жүргізілген зерттеудің теориялық-әдіснамалық негізі ретінде ауыл шаруашылығын материалдық-техникалық қамтамасыз ету бойынша отандық және шетелдік экономист-ғалымдардың ғылыми еңбектері, Қазақстан Республикасы Үкіметі қаулылары, заңнамалық актілері пайдаланылды.

Зерттеу жүргізу барысында зерттеудің мақсаты мен міндеттеріне байланысты әр түрлі зерттеу әдістері қолданылды: абстрактты-логикалық - аграрлық саланың техникалық базасының даму бағыттарын зерттеу үшін; монографриялық - алыс және жақын шет елдердің ауыл шаруашылығы тауар өндірушілердің техникалық базасын қалыптастыру жөніндегі тәжірибесін қорыту кезінде; экономика-статистикалық - агроөнеркәсіп өндірісі материалдық-техникалық базасы қазіргі жағдайын талдауда.

Зерттеудің ақпараттық базасы ретінде Қазақстан Республикасы Ұлттық экономика министрлігінің Статистика комитетінің, Ауыл шаруашылығы министрлігінің деректері, ауыл шаруашылығы машина жасау кәсіпорындарының ресми сайттарының және ауыл шаруашылық кәсіпорындарының есептік құжаттары, ғылыми-зерттеу мекемелердің статистикалық деректері пайдаланылды. Зерттеу тақырыбына байланысты отандық және шетелдік жарияланымдар мен ғылыми-теориялық, ғылыми-практикалық конференциялар материалдары, бұқаралық ақпарат құралдарының материалдары, мерзімді басылым мақалалары қолданылды.

Нәтижелер және оларды талқылау. Бүгінгі таңда ауылдық жерлерде республика халқының 43,1\% тұрады және ауыл шаруашылығы өндірісінің даму дәрежесіне халықтың өмірлік деңгейі ғана емес, азаматтар көпшілігінің әл-ауқаты да тікелей байланысты. Коронавирустық пандемияға қарамастан, республиканың агроөнеркәсіптік кешені 2020 жылы іс жүзінде барлық макро көрсеткіштер бойынша жақсы өсу динамикасын көрсетті. Жалпы, ауыл шаруашылығының жалпы өнім көлемі 5,6\% артып, 6,3 трлн теңгені құрады. Бұл Еура- 
зиялық экономикалық одақ елдері арасындағы ең үлкен өсім [5].

Өткен жылы азық-түлік өндірісі 4\%, ауыл шаруашылығының негізгі капиталына инвестициялар ағыны 15\%, азық-түлік өндірісіне 13,5\% өсті. Ауыл шаруашылығы министрлігінің алдына АӨК еңбек өнімділігін 2,5 есеге арттыру, өңделген өнім экспортын 2 есеге ұлғайту, ішкі нарықты 80\%-дан астам деңгейде азық-түлік тауар- ларымен толықтыру және 1 млн ауыл тұрғындарының табысын тұрақты арттыру бойынша міндеттер қойылды.

Ауыл шаруашылығы өндірісі дамуының жоғары деңгейі материалдық-техникалық базасының мүмкіндіктеріне тікелей байланысты. Сондықтан 2013-2020 жылдар аралығында ауыл шаруашылығын негізгі техника түрлерімен қамтамасыз етілу көрсеткіштеріне талдау жүргізілді (1 кесте).

1 кесте - Ауыл шаруашылығы техникасымен қамтамасыз етілу, 2013-2020 жж.

\begin{tabular}{|l|c|c|c|c|c|c|c|c|c|}
\hline \multirow{2}{*}{$\begin{array}{c}\text { Техниканың } \\
\text { атауы }\end{array}$} & 2013 & 2014 & 2015 & 2016 & 2017 & 2018 & 2019 & 2020 & $2013 /$ \\
\hline Тракторлар & 152,8 & 153,0 & 154,0 & 152,0 & 152,6 & 148,3 & 147,3 & 153,0 & 0,99 \\
\hline $\begin{array}{l}\text { Астық жинайтын } \\
\text { комбайндар }\end{array}$ & 45,6 & 49,4 & 44,3 & 42,0 & 41,5 & 40,0 & 38,5 & 42,0 & 1,08 \\
\hline Сепкіштер & 89,7 & 90,1 & 75,3 & 77,6 & 86,0 & 80,0 & 78,4 & 78,0 & 1,15 \\
\hline Жаткалар & 16,1 & 15,1 & 13,5 & 13,9 & 14,2 & 14,5 & 14,8 & 14,7 & 1,09 \\
\hline
\end{tabular}

Кестеден байқағанымыздай, қарастырылған мерзімде тракторлардан басқа ауыл шаруашылығын негізгі техникамен қамтамасыз етілу деңгейі едәуір төмендеген. Мысалы астық жинайтын комбайндар саны 45,6 мың данадан 42,0 мың данаға (1,08 есе), сепкіштер 89,7 мың данадан 78,0 мың данаға (1,15 есе) және жаткалар 16,1 мың данадан 14,7 мың данаға (1,09 есе) кеміген. Соның әсерінен 100 га егіс алқабына тиесілі еңбектің энергиямен жарақтандырылуы да төмендеген. Қазақстан ауыл шаруашылығындағы еңбек өнімділігі ЕО елдеріне қарағанда 8-10 есе төмен, ал жұмсалатын энергия шығындары мен басқа да материалдық ресурстар 3-5 есе көп.

Мемлекет қолдауы арқылы ауыл шаруашылығы техникасын Қазақстанда шығару үшін бірнеше кәсіпорын ашылған. Ол кәсіпорындар астық жинайтын комбайндар, ауыл шаруашылығы тракторлар, пресс-іріктеушілер, сепкіштер шығарады. Бұл кәсіпорындар «Минск трактор зауыты» және «Гомсельмаш» АҚ (Беларусь Республикасы), сондай-ақ «Ростсельмаш» және «Петербург трактор зауыты» ЖАҚ (Ресей) кәсіпорындарымен бірлесе жұмыс жасайды [6].

Ауыл шаруашылығы машиналарын шығаруда өзекті проблемаларының бірі ауыл шаруашылығы машиналары паркінің қолайсыз жай-күйі болып табылады. Қазақстанда ауыл шаруашылығы техникасының тозуы шамамен 80\% құрайды. Қазақстан Республикасы Ауыл шаруашылығы министрлігінің деректері бойынша астық жи- найтын комбайндардың $68 \%$ және тракторлардың 86\% орташа жасы нормативтік пайдалану мерзімі 8-10 жыл болған кезде 13-18 жасты құрайды. Тек комбайндардың $32 \%$ және тракторлардың 14\% орташа жасы 10 жылға дейін. Бұдан басқа, астық жинайтын комбайндардың 70\%-дан астамы, тракторлардың 80\%, жаткалардың 75\% және сепкіштердің 80\% есептен шығарылуға жатады.

Есептеулерге сәйкес, ел аумағында ауыл тауар өндірушілерінің тракторларды жаңартуға қажеттілігі - 8 мың бірлік комбайндар, 4 мың бірлік сепкіштер мен жаткалар жылына 1 мың бірлікті құрайды.

Қазіргі кезеңде отандық «Агромаш Холдинг KZ» АҚ, «СемАЗ» ЖШС, «Агротехмаш» ЖШС және «ДонМар» ЖШС ауыл шаруашылығы машина жасау ірі кәсіпорындарында тракторлар, астық жинайтын комбайндар, жаткалар және тағы басқа техника шығарылады (2 кесте).

2 кестедегі ауыл шаруашылығы техникасының түрлері біздің республикада кеңінен тараған. «Вектор» 410KZ, ACROS $550 K Z$ комбайндары «Ростсельмаш» бренді негізінде жасалған. Комбайн жинақтауда Қазақстандық бөлшектердің үлесі $40 \%$ құрайды, ал негізгі бөлшектері Ресей мен Беларусьтен әкелінеді. Бұл зауыттың өндірістік қуаты жылына құны 11 млрд. теңгені құрайтын 300 комбайн шығару. "ДонМар» ЖШС республикамыздағы барлық комбайндар түріне тіркемелі және аспалы жаткалар шығаратын жалғыз кәсіпорын [7]. 
2 кесте - Ауыл шаруашылығы машина жасау кәсіпорындары мен шығарылатын өнімі

\begin{tabular}{|c|c|}
\hline Өндірістік кәсіпорын аталуы & Шығарылатын өнімі \\
\hline $\begin{array}{l}\text { «Агромаш Холдинг KZ» АҚ, } \\
\text { Қостанай қ. }\end{array}$ & $\begin{array}{l}\text { Essil K3C-730, 740, 750, } 760 \text { комбайндары; LOVOL-354, 604, } \\
\text { 904, 1304, } 1804 \text { тракторлары; Кировец К-730, 735, 739, } 742 \\
\text { тракторлары; тұқым сепкіштер, жаткалар, П3-3,4 іріктеуші } \\
\text { платфрорма }\end{array}$ \\
\hline «СемАЗ» ЖШС, Өскемен қ. & «Беларус» 1221.1; 3022; 80.1; 82.1; 892 тракторлары \\
\hline «Агротехмаш» ЖШС, Қостанай қ. & К-744 тракторы; ACROS 530 комбайны; фронталды-тиеуші \\
\hline «ДонМар» ЖШС, Қостанай қ. & $\begin{array}{l}\text { Тіркемелі, аспалы жаткалар (7-16 м); Precision Aisrill тұқым } \\
\text { сепкіш кешені }\end{array}$ \\
\hline $\begin{array}{l}\text { «Вектор» комбайн зауыты», } \\
\text { Көкшетау қ. }\end{array}$ & «Вектор» 410KZ, ACROS 550KZ комбайндары \\
\hline
\end{tabular}

Орта сыныптағы ең қолжетімді трактор «Беларус» (МТ3) деп есептеуге болады. Оның орташа құны 7,4-8 млн теңге. Бұл сегменттегі кең бәсекелестікті «Агромаш Холдинг KZ» АҚ ел үшін салыстырмалы түрде жаңа «LOVOL» брендімен құрайды. Шығарылатын желіде өз сыныбындағы ең жеңіл және ең қолжетімді трактор LOVOL 354, ол 4,2 млн теңге тұрады. Нарықтағы ең қымбат баға В $(6110,6135)$ тракторлары бар «John Deere» бренді болып табылады, олардың құны айтарлықтай жоғары - 18-34 млн теңге. Қазақстанда жаңа комбайндардың бағасы 45-49 млн теңгеден басталады. Ең қолжетімді техниканы Engineering Ltd (Vec-tor, Acros) және «АгромашХолдинг KZ» АҚ (Essil) кәсіпорындары ұсынады. Импорттық комбайндар құны шамамен 95140 млн теңгені құрайды [8].

Қазақстанда ауыл шаруашылығы техникасы паркін жаңарту үшін инвестициялық субсидиялау бағдарламасы жұмыс істейді, ол сатып алынған отандық немесе импорттық техника құнының $25 \%$ өтеуді қарастырады. Бұл ретте субсидиялау нормативін облыс әкімдіктері жергілікті бюджет қара-жаты есебінен 35\%-ға дейін ұлғайта алады.

Отандық ауыл шаруашылығы машиналар шығаратын кәсіпорындардың өндірістік көрсеткіштерінде соңғы жылдары оң тенденция байқалады. Мысалы 2020 жылы жалпы құны 23,9 млрд. теңге құрайтын 730 трактор шығарылған. Ал 2019 жылы жалпы құны 16,6 млрд. теңге құрайтын 429 трактор шығарылған, өсу деңгейі 1,7 есе.

Әлемде тракторларды жаңартудың нормативтік деңгейі парктің жылына 10\% болып саналады [9]. Іс жүзінде біздің мемлекетімізде қаралған кезеңде (соңғы бес жыл) жыл сайын орта есеппен 30 млрд. теңгеге 2,6 мың трактор сатып алынды. Жаңарту деңгейі 1,7\% құрады - нормативтік көрсеткіштен 6 есе төмен.
Комбайндардың нормативтік жаңарту деңгейі - жылына 12,5\%. Қазақстан үшін бұл жыл сайын 233 млрд. теңгеге 4,9 мың машина сатып алу қажеттігін білдіреді. Іс жүзінде жылына 52 млрд. теңгеге 1,3 мың комбайн сатып алынды. Жаңарту деңгейі 3,9\% құрады, бұл нормативтен 3,2 есе төмен. Біздің мемлекет аумағында шығарылатын машиналар номенклатурасы мен саны бойынша жеткіліксіз болғандықтан, негізгі сұраныс Беларусь, Ресей, Украина және алыс шетелдерден импорттық жеткізілімдер есебінен қанағаттандырылады. Қазақстан Республикасына ауыл шаруашылығы техникасын жеткізушілер туралы ақпарат 3 кестеде келтірілген.

Кестеден көріп отырғанымыздай, шетелдік ауыл шаруашылығы техникасын жеткізетін фрирмалар Қазақстанның барлық аумағында орналасқан. Бірақ бұл техниканы сатып алуға кез келген шаруа қожалығының қаржылық жағдайы көтермейді. Сатып алған күннің өзінде де бұл техникаға техникалық қызмет көрсету шығындары да айтарлықтай.

Біздің республикамызда климаттық жағдайлардың әртүрлілігіне байланысты әр аймақта ауыл шаруашылық техника түрлерін қолдану ерекшеліктері бар.

Республика солтүстігінде негізгі ауыл шаруашылық дақыл болып жаздық бидай саналады [10]. Бұл аймақтың табиғи-климаттық жағдайына байланысты егін егу жұмыстары 10-12 күнде, ал егін жинау жұмыстары 15-20 күнде аяқталуы тиіс. Сондықтан, еліміздің солтүстік аймағында негізінен «Джон-Дир», «Клаас» тракторларына тіркелген «Джон-Дир», «Борго», «Хорш», «Морис» егіс кешендері қолданылады. Жаздық бидай егіс алқабының 30\% аталған техникаға тиесілі, қалған егіс алқабында отандық СЗС-2,1 сепкіштер қолданылады. 
3 кесте - Қазақстан Республикасына ауыл шаруашылығы техникасын жеткізушілер

\begin{tabular}{|c|c|c|}
\hline Компания аталуы & Орналасу орны & Ұсынатын өнімі \\
\hline $\begin{array}{l}\text { «IPC Agri» ЖШС - CNH } \\
\text { корпорациясы (Case } \\
\text { New Holland) }\end{array}$ & $\begin{array}{l}\text { Астана, Қостанай, } \\
\text { Көкшетау, Алматы, } \\
\text { Ақтөбе, Орал, Шымкент, } \\
\text { Атбасар }\end{array}$ & $\begin{array}{l}\text { Тракторлар, тұқым сепкіштер, астық } \\
\text { жинайтын комбайндар, топырақ өңдеу } \\
\text { техникасы, өздігінен жүретін және } \\
\text { тіркемелі бүріккіштер, астық тиегіштер, } \\
\text { орамалы және түкті пресс-іріктегіштер }\end{array}$ \\
\hline $\begin{array}{l}\text { «Eurasia Group» ЖШС - } \\
\text { «John Deere» }\end{array}$ & $\begin{array}{l}\text { Астана, Қостанай, } \\
\text { Көкшетау, Алматы, } \\
\text { Ақтөбе, Орал, Шымкент, } \\
\text { Карағанды, Петропавл, } \\
\text { Павлодар, Өскемен }\end{array}$ & $\begin{array}{l}\text { Комбайндар, тракторлар, жаткалар, } \\
\text { топырақ өңдеу техникасы, егіс жабдығы, } \\
\text { өздігінен жүретін және тіркемелі } \\
\text { бүріккіштер, пресс-іріктегіштер, астық } \\
\text { бункерлері }\end{array}$ \\
\hline $\begin{array}{l}\text { «Агромашхолдинг» АҚ - } \\
\text { «Гомсельмаш» Холдингі }\end{array}$ & $\begin{array}{l}\text { Өскемен, Көкшетау, } \\
\text { Петропавл, Қостанай, } \\
\text { Алматы, Ақкөл, Есіл } \\
\end{array}$ & $\begin{array}{l}\text { Комбайндар, тракторлар, жаткалар мен } \\
\text { егін жинайтын жабдық, тұқым сепкіштер, } \\
\text { жартылай тіркемелер }\end{array}$ \\
\hline $\begin{array}{l}\text { «Канди-Алматы» ЖШС - } \\
\text { «Бобруйск-агромаш» } \\
\text { ААҚ, «Лидсельмаш» } \\
\text { ААҚ, Харьков трактор } \\
\text { зауыты ААҚ }\end{array}$ & $\begin{array}{l}\text { Алматы, Шымкент, } \\
\text { Көкшетау, Ақтөбе, } \\
\text { Қостанай }\end{array}$ & $\begin{array}{l}\text { Комбайндар, топырақ өңдеу техникасы, } \\
\text { астық тазалау техникасы, жемшөп жинау } \\
\text { техникасы, тракторлар, тіркемелер }\end{array}$ \\
\hline $\begin{array}{l}\text { «СТ Агро Гмбх» ЖШС - } \\
\text { Claas, Horsch, Lemken, } \\
\text { Morris, Mac Don }\end{array}$ & $\begin{array}{l}\text { Астана, Қостанай, } \\
\text { Көкшетау, Алматы, } \\
\text { Петропавл, Павлодар, } \\
\text { Ақтөбе, Өскемен } \\
\end{array}$ & $\begin{array}{l}\text { Комбайндар, тракторлар, жаткалар, } \\
\text { тұқым сепкіштер, бүріккіштер, } \\
\text { культиваторлар }\end{array}$ \\
\hline $\begin{array}{l}\text { «Казростсервис» ЖШС } \\
\text { - «Ростсельмаш» ЖШҚ }\end{array}$ & $\begin{array}{l}\text { Астана, Көкшетау, } \\
\text { Қарағанды, Петропавл, } \\
\text { Павлодар, Өскемен, Есіл }\end{array}$ & $\begin{array}{l}\text { Комбайндар, тракторлар, тұқым } \\
\text { сепкіштер, бүріккіштер, топырақ өңдеу } \\
\text { техникасы, шөп оратын техника }\end{array}$ \\
\hline $\begin{array}{l}\text { «Borusan Makina» } \\
\text { компаниясы - } \\
\text { «Caterpillar» }\end{array}$ & $\begin{array}{l}\text { Астана, Ақтау, Қостанай, } \\
\text { Алматы, Атырау, Орал, } \\
\text { Сатпаев, Өскемен, } \\
\text { Көкшетау, Қарағанды }\end{array}$ & $\begin{array}{l}\text { Астық жинайтын комбайндар, шөп } \\
\text { жинайтын жабдық, өздігінен жүретін } \\
\text { бүріккіштер, тракторлар }\end{array}$ \\
\hline $\begin{array}{l}\text { «EurAsia Global Equip- } \\
\text { ment» ЖШС - «Foton } \\
\text { Lovol» (Қытай) }\end{array}$ & Алматы & Тракторлар \\
\hline
\end{tabular}

Республиканың оңтүстік аймағында соя, дәнге жүгері, мақта, қант қызылшасы, көкөніс дақылдары өсіріледі. Негізгі технологиялық операцияларды орындауға Ресей, Беларусь, Украинада жасалған ПЛН-335 үш корпусты соқа, БДН-1,8 делегейлік тырмалар (Беларусь, Украина), СУПН-6 сепкіштер (Украина) қолданылады. Негізгі трактор болып Беларус-80, 82 табылады.

Республикада ауыл шаруашылығы өндірісін табысты жүргізу үшін қуатты техникалық әлеует қажет. Біздің пікірімізше, аграрлық өнім шығаруға маманданған Қазақстан ауыл шаруашылығы техникасының импортына 90\% тәуелді болмауы тиіс. Техникалық базаның жетіспеушілігі және оны шетелдік машиналар есебінен қалыптастыру, техникалық жағынан неғұрлым дамыған елдермен баламалы емес алмасу есебінен ұлттық байлықтың кемуіне әкелуі мүмкін.

Түптеп келгенде, ауыл шаруашылығы техника паркін жаңарту Қазақстанның аг- рарлық саласының алдында тұрған еңбек өнімділігін 2015 жылы ауыл шаруашылығында жұмыспен қамтылған 1 адамға 1,2 млн теңгеден 2021 жылға қарай ауыл шаруашылығында жұмыспен қамтылған 1 адамға 3,7 млн теңгеге дейін ұлғайту міндетін орындау үшін негізгі үлес болады.

Ауылды материалдық-техникалық қамтамасыз ету проблемаларын шешу республикалық және облыстық деңгейде АӨК және өнеркәсіптің ресурстарын құрайтын салаларды қаржылай қолдау бөлігінде мұқият тексерілген мемлекеттік саясатты жүргізуді, басымдықтарды айқындауды, АӨК және ауыл шаруашылығы машиналарын жасау кәсіпорындарының қызметінде үлкен келісімділікті, нарықтық тетіктерді пайдалануды ескере отырып, осы кәсіпорындарды кредиттеудің жаңа схемаларын әзірлеуді талап етеді.

Қорытынды. Ауыл шаруашылығының техникалық базасын жаңарту үшін отандық ауыл шаруашылығы машина жасау өнді- 
рісін дамыту қажет. Машина жасау өндірісінің өндірістік мүмкіндігін кеңейту үшін келесі іс-шараларды жүзеге асыру қажет:

- бәсекелестікке төтеп беретін өнім өндіру үшін, өндірістік жабдықтар мен патентталған жаңа технологияларды сатып алуға қаражат бөлу. Бұл мақсаттарға елдің басты байлығы - мұнайды сатудан түскен қаражаттың едәуір бөлігі бағытталуы тиіс, оларды зауыттарға жеңілдік шарттарында ұзақ мерзімді кредиттер түрінде беру қажет;

- республикада шығарылатын машиналардағы отандық компоненттердің үлесін біртіндеп 60-80\%-ға дейін ұлғайта отырып, заманауи ауыл шаруашылығы техникасын шығару жөніндегі бірлескен өндірістерді құруға мемлекеттік қолдау қажет;

- тікелей шетелдік инвестицияларды тарта отырып, заманауи сервистік қызметті ұйымдастыру. Ауыл шаруашылығы машиналарын жасаудың болашақ өндірушілері мен әлеуетті инвесторларын іріктеу критерийлерін мемлекет тарапынан белгілеу;

- ауыл тұрғындарының жаңа машиналарға қажеттілігін қамтамасыз ету проблемасын шешу үшін, олардың қаржылық мүмкіндіктерінің шектеулі болуы жағдайында қолда бар техниканы, оның бөлшектерін, агрегаттарын жөндеу және қалпына келтіру, қосалқы бөлшектер жасау мәселесі өткір тұр. Бұл қалған ауыл шаруашылығы машиналары паркінің маусымдық жұмыстарға дайындығын арттырудың ең тиімді тәсілдерінің бірі;

- әр түрлі интеграциялық құрылымдар шеңберінде ауыл шаруашылығы машиналарын өндіруді бірлесіп ұйымдастыру желісін одан әрі кеңейту, бәсекелес машина жасау кәсіпорындарын дамыту, квоталар, дайын өнімді, жинақтаушы бұйымдарды, металдарды, қосалқы бөлшектерді, басқа да материалдарды өзара жеткізуге арналған бағалар туралы мәселелерді қарастыру;

- ішкі нарықтағы өнімнің қауіпсіздігі мен сапасын арттыруға бағытталған техникалық реттеу жүйесін жетілдіру және экспорттық нарықтардағы техникалық кедергілерді еңсеру.

\section{әдебиеттер тізімі}

[1] Молдашев, А.Б. Проблемы устойчивого функционирования продовольственной системы Республики Казахстан / А.Б. Молдашев, Г.А. Никитина // Проблемы агрорынка. -2019.- №2. - С.11-19.

[2] Статистический сборник «Сельское, лесное и рыбное хозяйство в Республике Ка- захстан». Комитет по статистике МНЭ РК [Электронный ресурc]. - 2021. - URL: http: //www.stat.gov.kz/ (дата обращения: 19.03. 2021).

[3] Государственная программа развития агропромышленного комплекса Республики Казахстан на 2017-2021 гг.-Астана, 2017.- 94 c.

[4 Анализ производства (локализации) сельскохозяйственной техники в Евразийском экономическом союзе по видам производства. - М., 2017.- 22 с.

[5] Омаров, С. Государственная поддержка АПК станет стабильной и адекватной / С. Омаров // Аграрий Казахстана. - 2021.№5. - C. 4-5.

[6] В Казахстане лишь каждый десятый трактор отечественного производства [Электронный ресурc].-2021.-URL: -http://agrosektor.kz/ agriculture-news/v-kazahstane-lish-kazhdyj- desyatyj- traktor-otechestvennogo-proizvodst-va.html?searched/ (дата обращения: 12. 02.2021).

[7] Официальный сайт ТОО «ДонМар» [Электронный ресурc]. - 2021. - URL: https:// www.donmar.kz (дата обращения: 10.03 . 2021).

[8] Рынок сельхозтехники: самая доступная и дорогая техника [Электронный pecypc]. - 2021. - URL: https://akab.kz/rynokselhoztehniki- v- rk- samaya-dostupnaya-i-dorogaya-tehnika/ (дата обращения: 20.03.2021).

[9] Ибришев, Н.Н. Ресурсы как основа эфффективного функционирования аграрной отрасли / Н.Н. Ибришев // Проблемы агрорынка. -2019.- №1. - С.40-48.

[10] Кешуов, С.А. Современное состояние и перспективы сельскохозяйственного машиностроения Республики Казахстан // Сельскохозяйственная техника: Материалы Междунар. научн.-технич. конф. - Алматы, 2015. - C.12-15.

\section{References}

[1] Moldashev, A.B. \& Nikitina, G.A. (2019). Problemy ustojchivogo funkcionirovaniya prodovol'stvennoj sistemy Respubliki Kazahstan [Problems of sustainable functioning of the food system of the Republic of Kazakhstan]. Problemy agrorynka - Problems of AgriMarket, 2, 1119 [in Russian].

[2] Statisticheskij sbornik «Sel'skoe, lesnoe i rybnoe hozyajstvo v Respublike Kazahstan». Komitet po statistike MNE RK [Statistical collection "Agriculture, forestry and fisheries in the Republic of Kazakhstan". Committee on Statistics of MNE RK]. [Electronic resource]. - 2021 Available at: http: //www. stat.gov.kz (date of access: 19.03.2021) [in Russian].

[3] Gosudarstvennaya programma razvitiya agropromyshlennogo kompleksa Respubliki 
Kazahstan na 2017-2021 gody (2017) [The

State program for the development of the agroindustrial complex of the Republic of Kazakhstan for 2017-2021]. Astana, 94 p. [in Russian].

[4] Analiz proizvodstva (lokalizacii) sel'skohozyajstvennoj tekhniki $v$ Evrazijskom ekonomicheskom soyuze po vidam proizvodstva (2017) [Analysis of production (localization) of agricultural machinery in the Eurasian Economic Union by types of production]. Moscow, 22 p. [in Russian].

[5] Omarov, S. (2021). Gosudarstvennaya podderzhka APK stanet stabil'noj i adekvatnoj [State support of agro-industrial complex will become stable and adequate]. Agrarij Kazakstana - Agrarian of Kazakhstan. 5, 4-5 [in Russian].

[6] «V Kazahstane lish' kazhdyj desyatyj traktor otechestvennogo proizvodstva» ["In Kazakhstan, only every tenth tractor of domestic production"] [Electronic resource]. - 2021 Available at: https://agrosektor.kz/agriculturenews / м kazahstane lish kazhdyj desyatyj traktor otechestvennogo proizvodstva.html? searched (date of access: 12.02.2021) [in Russian].
[7] Oficial'nyj sajt TOO «DonMar» [Official website of DonMar LLP]. [Electronic resource]. 2021 - Available at: https://www.donmar.kz (date of access: 10.03.2021) [in Russian].

[8] Rynok sel'hoztekhniki: samaya dostupnaya i dorogaya tekhnika [Agricultural machinery market: the most affordable and expensive machinery]. [Electronic resource]. - 2021 Available at: https://akab.kz/rynok selhoztehniki v rk samaya dostupnaya i dorogaya tehnika / (date of access: 20.03.2021) [in Russian].

[9] Ibrishev, N.N. (2019). Resursy kak osnova effektivnogo funkcionirovaniya agrarnoj otrasli [Resources as the basis for the effective functioning of the agricultural industry]. Problemy agrorynka - Problems of AgriMarket, 1. 4048 [in Russian].

[10] Keshuov, S.A. (2015). Sovremennoe sostoyanie i perspektivy sel'skohozyajstvennogo mashinostroeniya Respubliki Kazahstan [Current state and prospects of agricultural engineering of the Republic of Kazakhstan] // Sel'skohozyajstvennaya tekhnika // Agricultural machinery. Materialy Mezhdunar. nauchn.-tekhnich. konf. Almaty, pp. 12-15 [in Russian].

\section{Авторлар туралы ақпарат:}

Молдашев Алтынбек Бакирович - негізгі автор; экономика ғылымдарының докторы, профессор; бас ғылыми қызметкері; Қазақ аграрлық-өнеркәсіптік кешенінің экономикасы және ауылдық аумақтарды дамыту ғылыми-зерттеу институты; 050057 Сатпаев көш., 30б, Алматы қ., Қазақстан; e-mail:moldashev48@mail.ru; https://orcid.org/0000-0003-3987-4648

Камысбаев Марат; экономика ғылымдарының докторы, профессор; «Экономика және бизнес» кафедрасының профессоры; Халықаралық ақпараттық технологиялар университеті; 050040 Манаса көш., 34/1, Алматы қ., Қазақстан; e-mail: marat.kamysbayev@gmail.com; https://orcid.org/0000-0002-6592-6030

\section{Information about authors:}

Moldashev Altynbek - The main author; Doctor of Economic Sciences, Professor; Chief researcher; Kazakh Research Institute of Economy of Agro-Industrial Complex and Rural Development; 050057 Satpaev str., 30b, Almaty, Kazakhstan; e-mail: moldashev48@mail.ru; https://orcid.org/0000-0003-39874648

Kamysbayev Marat; Doctor of Economic Sciences, Professor; Professor of Department of Economics and Business; International University of Information Technologies; 050040 Manas str., 34/1, Almaty, Kazakhstan; e-mail: marat.kamysbayev@gmail.com; https://orcid.org/0000-0002-6592-6030

\section{Информация об авторах:}

Молдашев Алтынбек Бакирович - основной автор; доктор экономических наук, профессор; главный научный сотрудник; Казахский научно-исследовательский институт экономики агропромышленного комплекса и развития сельских территорий; 050057 ул. Сатпаева, 30б, г.Алматы, Казахстан; e-mail: moldashev48@mail.ru; https://orcid.org/0000-0003-3987-4648

Камысбаев Марат Куралбекович; доктор экономических наук, профессор; профессор кафедры «Экономики и бизнеса»; Международный университет информационных технологий; 050040 ул. Манаса, 34/1, г. Алматы, Казахстан; e-mail: marat.kamysbayev@gmail.com; https://orcid.org/0000$0002-6592-6030$ 